Довгунь О.С., Стасюк К.3.

\title{
АВТОМАТИЗАЦІЯ ЛОГІСТИКИ: СУЧАСНI РІШЕННЯ ТА ПЕРСПЕКТИВИ
}

\begin{abstract}
Обтрунтовано доцільність автоматизації логістичних процесів. Досліджено ринок вітчизняних програмних рішень, які надають широкі можливості автоматизаџіï, залишаючись доступними для украӥнських компаній. Визначено основні конкурентні переваги, які забезпечує автоматизація, та наведено приклади, в яких процесах автоматизація на сьогодні допомагає (зокрема зменшити різного роду витрати, збільшити доступ до інформачї, досягти зростання точок обслуговування, відстежувати замовлення та стан маршрутів). Сформульовано принщипи, які на сьогодні варто враховувати підприємствам для успішного впровадження логістичних інформаційних систем. Подано висновки щзодо можливостей розвитку украӥнських підприємств за рахунок впровадження спеціалізованих програмних рімень.
\end{abstract}

Ключові слова: автоматизачія логістичних прочесів, автоматизачія транспортних перевезень, інформаційні системи, електронний документообіг, СЕД.

Постановка проблеми. У сучасному світі комп'ютерні технології стали універсальним інструментом, який використовується практично у всіх сферах економічної діяльності. Логістика не $\epsilon$ винятком. Інформаційні технології можуть позитивно вплинути на основні аспекти логістичної діяльності, зокрема:

- контроль транспортних перевезень;

• оперативний доступ до інформації щодо ресурсів на складах;

- спілкування 3 клієнтом в реальному часі, моніторинг виконання його замовлення;

- автоматизація подачі звітності до контролюючих органів.

У світі активно розвиваються інформаційні системи для автоматизації таких логістичних процесів. Тим не менш економічна ситуація в країні робить використання закордонних інструментів надто дорогим для українського підприємства. У таких умовах актуальним постає питання розгляду можливостей автоматизації логістики, які пропонують вітчизняні IT компанії.

Аналіз останніх досліджень та публікацій. В умовах конкурентного середовища, коли складна економічна ситуація зумовлює необхідність пошуку нових способів оптимізації логістичних процесів, використання інформаційних технологій може бути вирішенням багатьох проблем. Дослідження

(C) Довгунь Оксана Степанівна, к.е.н., асист. каф. маркетингу i логістики, Національний університет «Львівська політехніка», тел.: +380969802704, e-mail: Oksana.dovhun@gmail.com

Стасюк Катерина Зіновї̈вна, студентка, Національний університет «Львівська політехніка», тел.: +380676824615, e-mail: kuzyk.katheryna@gmail.com сучасних наукових публікацій показують, що багато авторів розкривають технічні можливості оптимізації. Так Салікова І.С. в своїй роботі [1], а також Бабенко А.О. [2] висвітлюють теоретичні аспекти можливостей оптимізації діяльності логістичних компаній за рахунок використання інформаційних систем. А такі автори, як Руда М. В., Боднар Т. ., Денисова К. О., Анісімова О. М. пропонують використовувати системи електронного документообігу i описують конкурентні переваги, які забезпечують такі системи $[3,4]$. Розглянуті наукові роботи доводять, що застосування інформаційних технологій дозволяє підвищити ефективність логістичних процесів. Поряд з цим автори описують теоретичні аспекти i можливості, а підприємствам необхідні також програмні рішення, які дозволили б реалізувати всі вказані можливості.

Формулювання цілей статті. Метою статті $\epsilon$ дослідження сучасних програмних рішень та перспектив автоматизації логістичних процесів.

Опис основного матеріалу дослідження. Відколи інформаційні системи набули масового поширення, для підприємств відкрилася низка можливостей. IT системи дозволяють різними способами підвищити ефективність роботи підприємства. Їх характеризують як засоби стратегічної гнучкості [5]. Тобто, інформаційні системи дозволяють накопичувати, обробляти i використовувати дані, щоб в подальшому на їх основі робити висновки щодо своєї ефективності в цілому, а також, можливо, приймати рішення щодо розширення своєї діяльності. У даній статті охарактеризуємо сучасні рішення та перспективи автоматизації транспортних перевезень та систему електронного документообігу. 
Розглянемо приклад - інформаційну систему складу. Інформаційна система проводить аудит всіх операцій на цьому складі; маючи вибірку операцій за певний період (наприклад пів року), система «розуміє» (тільки для прикладу), що 3 поточною кількістю замовлень в середньому третя частина складу залишається не зайнятою, що, в свою чергу, може бути основою для прийняття рішення щодо укладання більшої кількості контрактів або надання нових видів послуг. Так само інформаційна система може розрахувати, які товари вивозяться найшвидше повинні бути у зонах 3 найлегшим доступом, а які зберігаються довше - можуть бути розміщені у віддалених зонах. Це один з простих прикладів, але очевидно, що правильно прийняті рішення на основі аналізу даних дозволяють ефективно покращувати роботу будь-якої системи.

Серед основних причин невпинного поширення автоматизованих систем та рішень $€$ більша надійність, контроль, прозорість виконаної роботи та ін. Логістичні процеси не $\epsilon$ винятком. Для прикладу, визначимо декілька переваг, які пропонує автоматизація транспортних перевезень:

- виключення помилок ручної обробки даних;

- доступність даних для аналізу і прийняття рішень;

- $100 \%$ аудит всіх витрат;

- можливість відстеження статусу замовлення в реальному часі;

- відстеження стану маршрутів і оперативна їх зміна у випадку непередбачуваних ситуацій та ін.

Вигоди від впровадження інформаційних технологій підтверджуються дослідженнями експертів. Так SystemGroup Україна - провідний системний інтегратор України в області автоматизації торгівлі, складу i виробництва, провели дослідження щодо переваг впровадження інформаційних систем управління транспортними перевезеннями. Результати цього досвідчення свідчать, що такі системи дозволяють [6]:

- знизити затрати на утримання автопарку на $15-25 \%$

- знизити витрати на паливо на 10-30\%;

- збільшити кількість точок обслуговування в день на 20-30\%;

- зменшити затрати на персонал на 20\%.

Позитивно, що такі системи автоматизації вже починають використовуватись. Окреслимо основні сучасні тенденції цього процесу. На 7-му міжнародному

Logistics Innovation Forum 2017 [7] керівник компанії Right Way - міжнародної онлайн платформи для планування, пошуку і управління вантажними перевезеннями Марина Пекерман висвітлила дані дослідження, які свідчать, що український ринок використовує різноманітні програми та онлайн платформи для управління логістикою і транспортними перевезеннями. В межах форуму була презентована одна 3 українських розробок у сфері автоматизації логістики - сервіс «Мурашина логістика», що автоматизує планування маршрутів та відповідних витрат [7]. Він надає низку можливостей, серед яких багатофакторна оптимізація маршрутів, представлення маршруту на пристрої водія, друк вихідних форм і карт, облік обов'язкових точок зупинки, інтеграція сервісу з обліковою системою користувача [8]. Після налаштування сервісу під конкретні умови функціонування підприємства він може стати незамінним помічником при побудові маршрутів.

Іншим прикладом української інформаційної системи, основне призначення якої полягає в оптимізації транспортних перевезень, $\epsilon$ Logist.ua [9]. Основною іiі перевагою $\epsilon$ модульна структура. В залежності від того, які процеси підлягають автоматизації, підприємство може самостійно приймати рішення, які модулі використовувати. Так модуль «Планування» виконує функції розглянутої вище системи, а саме аналізує вхідні дані маршрутів і на їх основі будує оптимальні маршрути, що враховують графіки роботи клієнтів, особливості транспорту i доріг, i навіть пріоритети. Прикладом іншого модуля $\epsilon$ «Моніторинг». Його робота базується на функції GPS-навігації, що дозволяє відстежувати рух транспорту в реальному часі. Це дозволяє фіксувати всі події, що відбуваються 3 автомобілем і дає можливість корегувати дії водіїв за потреби. Також у сервісі $є$ мобільні додатки, що робить можливим його використання не тільки стаціонарно, а i безпосередньо на транспортних засобах. Модульна структура i різноманітний набір функцій зумовлюють доцільність використання саме цієї системи, якщо на підприємстві планується поступова поетапна автоматизація [9].

Ще одним прикладом української логістичної системи $є$ Rational Logistics [9]. Ця компанія розробила ПЗ, відмінною рисою якого $\epsilon$ оптимізація не часу чи кілометражу, а собівартості доставки. Також розробники стверджують, що вони оперують тільки звичними для водіїв критеріями, а саме своєчасність і кількість доставок, час роботи на маршрутах, а також мобільний додаток для їхнього сервісу використовує найактуальнішу 
карту, так як вона постійно виправляється великою кількістю користувачів. Додатковою зручністю виступає можливість використання телефонів та планшетів на OC Android в якості GPS-трекерів, так як в основному водії вже користуються такими пристроями. Якщо підсумувати, то таку систему варто розглядати як спосіб автоматизації роботи логістичного підприємства, якщо воно використовує власний парк автотранспорту, і для нього $є$ важливим зручність і зрозумілість роботи 3 сервісом для своїх водіїв.

Таким чином відслідковується тенденція розвитку спеціалізованих IT-рішень, а також їх інтеграція в роботу логістичних компаній. Безумовно, автоматизація транспортних перевезень відкриває для логістичних компаній нові можливості, але для них можливий не тільки такий вид автоматизації. Важливим засобом автоматизації будь-якого підприємства, в тому числі, логістичного, $\epsilon$ використання систем електронного документообігу.

Система електронного документообігу (в подальшому СЕД) - організаційно-технічна система, що забезпечує процес створення, управління доступом і поширення електронних документів в комп'ютерних мережах, а також забезпечує контроль над потоками документів в організації. Використання таких систем відкриває цілий ряд можливостей для будь-яких компаній, що не зменшує їх важливості і для логістичних компаній в тому числі. Серед основних переваг електронного документообігу визначають [10]:

• повний контроль документообігу на будьякому етапі діяльності;

• скорочення кількості людських помилок і як результат - часу на їх пошук і виправлення;

- економія витратних матеріалів;

- прискорення процесів оформлення, відправки та обробки документів, можливість майже миттєвої їх доставки;

- підвищення рівня захисту документів та ін.

Підприємства повинні зважати й на певні недоліки СЕД. Основна проблема, пов'язана 3 використанням СЕД, полягає у тому, що розвиток цих технологій обумовив розробку різних стандартів обміну інформацією у різних галузях [11]. При впровадженні таких технологій керівникам підприємств слід мати на увазі, що розширення діяльності і підключення нових партнерів може вимагати суттєвої кількості робочих ресурсів для підтримки нового стандарту. Однак в межах однієї галузі логістики, коли набір супроводжуючої документації є відносно сталим, це не повинно спричиняти великих складнощів.

Одною 3 вітчизняних СЕД $\epsilon$ електронна система E-Doc, яка входить до складу цілого комплексу документів E-Com (TM EXITE) [12]. Розробники цієї системи стверджують, що вона забезпечує контроль супроводжувальних документів впродовж всього ланцюга поставок. До інших переваг можна віднести підтримку електронних підписів, що підвищує захищеність даних, а також можливість відправляти неструктуровані документи, що дозволяє обмінюватись нестандартизованими формами i документами, які визначені тільки всередині підприємства. Також сервіс підтримує подачу звітності до контролюючих органів, що пришвидшує цю процедуру. В загальному система виконує поставлені задачі i якщо компанія вже використовує якісь компоненти електронного сервісу E-Com, то варто розглянути автоматизацію роботи 3 документами, яка пропонується цим сервісом.

Іншою системою електронного документообігу, яка вже $є$ на ринку, $є$ система EDI від компанії Edisoft. Ця система теж пропонує повний контроль документообігу по всьому ланцюжку поставок. Але їі визначною рисою $є$ підтримка декількох стандартів електронних документів, а саме Edifact, X12, XML та інші [10]. Варто зауважити, що система дозволяє інтегруватися 3 обліковою системою компанії, що починає іiі використовувати, що теж є дуже зручно. Компанія Edisoft пропонує цілий набір електронних рішень для документообігу, тому система може підлаштовуватися під потреби конкретного підприємства.

Варто зауважити, що зараз на ринку представлено не багато українських СЕД систем. Для того, щоб такі системи почали активніше розвиватись, потрібно організовувати роботи 3 уніфікації торгових i фінансових процедур, стандартизації форм документів, сполучення вітчизняних СЕД з зарубіжними електронними службами та ін. [4].

Висновки та перспективи подальших досліджень. В цілому, якщо говорити про електронні рішення для логістики, то можна стверджувати, що вони дуже швидко розвиваються. В світі вже використовуються комплексні системи автоматизації бізнеспроцесів, i вітчизняні виробники прагнуть створити такі ж інструменти, які відповідали б і потребам логістичних підприємств, і залишалися доступними для них. Тим не менш є цілий ряд факторів, які стримують цей розвиток. Найсерйознішим 3 них виступає відсутність стандартизованих документів, які 
супроводжують увесь процес транспортування i зберігання вантажів, що змушує логістичні підприємства розробляти свої власні стандарти, що, в свою чергу, значно ускладнює автоматизацію. Але більша швидкість, надійність i підконтрольність роботи електронних систем зумовлює їх розвиток, незважаючи на складнощі. Нові рішення, такі як наприклад, GPS-навігація для відстеження поточного місцезнаходження товару, набувають все більшого поширення.

Для успішного впровадження логістичних інформаційних систем підприємствам слід дотримуватися наступних принципів:

- чітко сформулювати, яка саме сфера діяльності повинна бути автоматизованою;

- обрати програмне рішення, в переліку можливостей якого є всі необхідні функції для автоматизації обраної сфери діяльності;

- узгодити 3 виробником програмного забезпечення умови використання i технічної підтримки його продукту;

- провести навчання персоналу для ефективного використання всіх можливостей обраного програмного забезпечення.

Наведені вище кроки є лише базовими, але достатньо важливими. Крім того, слід розуміти, що існуючі системи для автоматизації логістичних процесів не $є$ ідеальними, вони тільки розвиваються. Передумовами до цього розвитку можуть бути: розуміння важливості автоматизації керівництвом, навчання персоналу i активне використання систем великою кількістю логістичних компаній. Таким чином, чим більша кількість підприємств інтегруватиме ці системи, тим більше ресурсів отримають їхні розробники для удосконалення $\mathrm{i}$ розвитку систем. Враховуючи зростання сфери логістичних послуг, хороша автоматизація, окрім зазначених переваг, буде сприяти втриманню підприємствами конкурентного положення на сучасному ринку, адже вимоги клієнтів постійно зростають.

Перспективами подальших досліджень $\epsilon$ аналізування інформації щодо ринкової частки кожного 3 розглянутих програмних засобів та основних переваг i недоліків, враховуючи історію їх використання підприємствами. Також важливим $\epsilon$ порівняння вітчизняних систем із зарубіжними аналогами, враховуючи те, який розвиток ці системи можуть отримати в майбутньому 3 метою оптимального вибору підприємствами тої чи іншої системи.

\section{ПЕРЕЛІК ВИКОРИСТАНИХ ДЖЕРЕЛ}

1. Салікова I. С. Використання інформаційних технологій і систем у логістичних системах для підвищення ефективності роботи підприємств / І. С. Салікова // Сучасні інформаційні технології та системи в управлінні - зб. матеріалів I Всеукр. наук.-практ. конф. молодих вчених, аспірантів і студентів - Київ: КНЕУ, 2017 - c. 174-176.

2. Бабенко А. О. Застосування сучасних інформаційних систем і технологій у діяльності логістичних компаній / А. О. Бабенко // Сучасні інформаційні технології та системи в управлінні - зб. матеріалів I Всеукр. наук.-практ. конф. молодих вчених, аспірантів і студентів - Київ: КНЕУ, 2017 - с. 14-16.

3. Руда М. В., Боднар Т. О. Роль електронного обміну даними у розвитку міжнародної логістики: глобальні тренди / М. В. Руда, Т. О. Боднар // Вісник національного університету «Львівська політехніка»№ 863 - Львів, вид-во Львівської політехніки, 2017 - с. 168-178.

4. Денисова К. О., Анісімова О. М. Електронні технології обміну даними в транспортній сфері / К.О. Денисова, О. М. Анісімова // Вісник студентського наукового товариства Донецького національного університету імені Василя Стуса - Випуск 8, том 2 - Вінниця: ДонНУ імені Василя Стуса, 2016 - c. 171-175.

5. Yang ChenYi WangEmail authorSaggi NevoJose BenitezGang Kou. Improving strategic flexibility with information technologies: insights for firm performance in an emerging economy / Yang ChenYi WangEmail authorSaggi NevoJose BenitezGang Kou // Journal of Information Technology - Том 32 - березень, 2017 - с. 10 25.

6. Как экономить до $30 \%$ на транспортной логистике [електронний ресурс] - Режим доступу: https://trademaster.ua/intervju/1690

7. VII-й ежегодный Logistics Innovation Forum 2017 [електронний ресурс] - Режим доступу: http://www.summitbiz.com.ua/index.php?option=com_content\&view=article\&id=97:logistics-innovation-forum2017\&catid=1:2009-12-28-01-26-59\&Itemid=69

8. Почужевський О. Д., Матвійчук О. П. Оптимізація транспортної системи підприємства шляхом використання сервісу «Муравьиная логистика» [електронний ресурс] - Режим доступу: http://eir.pstu.edu/bitstream/handle/123456789/14143/\%20.\%20123-124.pdf?sequence=1

9. Системи та програми для логістики керування транспортом [електронний ресурс] - Режим доступу: https://msb.aval.ua/business_it/logistic/

10. Електронний обмін даними в ланцюжку поставок [електронний ресурс] - Режим доступу: https://ediweb.com/uk-ua/solutions/edi 
11. Tarasenko М. A. Information technology in logistics / М. А. Tarasenko // Материалы I Всероссийской научно-технической конференции студентов, аспирантов и молодых ученых - Владивосток, 2016 - с. 36-40.

12. EDI-рішення для логістики від компанії E-Com [електронний ресурс]. - Режим доступу: https://www.slideshare.net/EcomUA/ss-52369818

\section{REFERENCES}

1. Salikova, I.S. (2017) Vykorystannya informatsiynykh tekhnolohiy i system u lohistychnykh systemakh dlya pidvyshchennya efektyvnosti roboty pidpryyemstv [Information technologies and systems using in logistics systems for improving efficiency of enterprises] / I.S. Salikova // Modern information technologies and systems in management - a digest of First Ukrainian scientific and practical young scientists, postgraduates and students conference (pp. 174-176). - Kyiv: KNEU [in Ukrainian].

2. Babenko, A.O. (2017) Zastosuvannya suchasnykh informatsiynykh system i tekhnolohiy u diyal'nosti lohistychnykh kompaniy [Modern information technologies and systems usage in activities of logistics companies] / A.O. Babenko // Modern information technologies and systems in management - a digest of First Ukrainian scientific and practical young scientists, postgraduates and students conference (pp. 14-16). - Kyiv: KNEU [in Ukrainian].

3. Ruda, M.B, Bodnar, T.O. (2017) Rol' elektronnoho obminu danymy u rozvytku mizhnarodnoyi lohistyky: hlobal'ni trendy [A role of electronic data interchange for international logistics development: global trends] / M.B. Ruda, T.O. Bodnar // Visnyk of Lviv Polytechnic National University (№ 863, pp. 168-178). - Lviv, Lviv Politechnic publishing [in Ukrainian].

4. Denysova, K.O, Anisimova, O.M. (2017) Elektronni tekhnolohiyi obminu danymy v transportniy sferi [Electronic technologies of data interchange in transportation area] / K.O. Denysova, O.M. Anisimova // Visnyk of students scientific society of Vasyl' Stus Donetsk national university (№ 8, Vol. 2, pp. 171-175). - Vinnitsa, Vasyl' Stus DonNU [in Ukrainian].

5. Yang Chen, Yi Wang, Saggi Nevo, Jose Benitez, Gang Kou (March 2017). Improving strategic flexibility with information technologies: insights for firm performance in an emerging economy / Yang Chen, Yi Wang, Saggi Nevo, Jose Benitez, Gang Kou // Journal of Information Technology (Vol. 32, pp. 10-25).

6. Kak ekonomyt' do $30 \%$ na transportnoy lohystyke [How to save up to $30 \%$ on transportation logistics]. trademaster.ua. Retrieved from: https://trademaster.ua/intervju/1690 [in Russian].

7. VII-y ezhehodniy Logistics Innovation Forum 2017 [VII-th annual Logistics
[ Innovation Forum 2017]. www.summitbiz.com.ua. Retrieved from:

http://www.summitbiz.com.ua/index.php?option=com_content\&view=article\&id=97:logistics-innovation-forum2017\&catid=1:2009-12-28-01-26-59\&Itemid=69 [in Russian].

8. Pochuszevsky, O.D, Matviychuk, O.P. Optymizatsiya transportnoyi systemy pidpryyemstva shlyakhom vykorystannya servisu «Murav'ynaya lohystyka» [Enterprise transportation system optimization using service "Ant logistics"]. eir.pstu.edu. Retrieved from: http://eir.pstu.edu/bitstream/handle/123456789/14143/\%20.\%20123124.pdf?sequence=1 [in Ukrainian].

9. Systemy ta prohramy dlya lohistyky keruvannya transportom [Systems and programs for transport management logistics]. msb.aval.ua Retrieved from: https://msb.aval.ua/business_it/logistic/ [in Ukrainian].

10. Elektronnyy obmin danymy $\mathrm{v}$ lantsyuzhku postavok [Electronic data interchange in deliveries chain]. ediweb.com. Retrieved from: https://ediweb.com/uk-ua/solutions/edi [in Ukrainian].

11. Tarasenko, M. A. (2016) Information technology in logistics / M. A. Tarasenko // Materials of the first AllRussian national and technical students, postgraduates and young scientists conference (pp. 36-40). - Vladivostok.

12. EDI-rishennya dlya lohistyky vid kompaniyi E-Com [E-Com EDI-solutions for logistics]. www.slideshare.net. Retrieved from: https://www.slideshare.net/EcomUA/ss-52369818 [in Ukrainian].

Одержано 14.09.2017p. 